\title{
Globalization and the German industrial production model
}

\author{
Gary Herrigel
}

Published online: 29 October 2014

(C) Institut für Arbeitsmarkt- und Berufsforschung 2014

\begin{abstract}
Globalization is transforming the German manufacturing production model. German manufacturing MNCs are shifting from servicing global demand via exports to a strategy of "produce where you sell" FDI expansion in emerging global markets. This strategy is generating recursive dynamics that are transforming the demographic and role composition of German home country production locations. This, in turn, poses challenges for the German systems of industrial relations and for industrial policy that are only beginning to be addressed. Overall, the article's take home conceptual message is that contemporary manufacturing globalization processes are recursive: i.e.: actions taken outside of Germany, on all levels, have consequences for-and involve change in —organizations and practices within Germany.
\end{abstract}

\section{Globalisierung und das deutsche Modell der Industrieproduktion}

Zusammenfassung Das deutsche Modell der Industrieproduktion befindet sich wegen der Globalisierung im

Much of the material in this paper draws on a series of research projects conducted by the author, often in collaboration with Volker Wittke and Ulrich Voskamp of the SOFI Institute in Goettingen, Germany. Over 150 interviews were conducted in Germany, Central Europe and China between 2008 and 2013 in the automobile, auto components, electromechanical and machinery industries. I thank the Alfred P Sloan Foundation and the Confucius Institute at the University of Chicago and we thank the Hans Boekler Stiftung for financial support. This article is dedicated to the memory of Volker Wittke, indispensible colleague and friend.

G. Herrigel $(\bowtie)$

University of Chicago,

Chicago, USA

e-mail: g-herrigel@uchicago.edu
Wandel. Produzierende multinationale Unternehmen verlagern ihren Schwerpunkt von der Bedienung der weltweiten Nachfrage über den Export nun hin zu einer Strategie von „dort produzieren wo man verkauft" (,produce where you sell“), wodurch deren Direktinvestitionen in den Emerging Markets zunehmen. Diese Strategie führt zu einer rekursiven Dynamik, die die Demographische- und Rollenverteilungen deutscher Produktionsstandorte im Inland verändert. Dies wiederum stellt eine Herausforderung für die Akteure innerhalb des deutschen Systems der industriellen Beziehungen und der Industriepolitik dar; und diese haben gerade erst begonnen, sich ihr zu stellen. Insgesamt besteht die Kernbotschaft dieses Beitrags darin, dass die aktuellen Prozesse der Produktionbsglobalisierung rekursiv sind, d.h. Schritte, die außerhalb Deutschlands unternommen werden, wirken sich auf allen Ebenen auf die Organisationsstrukturen und Verfahrensweisen innerhalb Deutschlands aus und verändern diese.

Globalization is transforming the German industrial production model. Traditionally, German manufacturers primarily focused on exports and positioned themselves in the high quality end of global markets. They competed by offering sophisticated and/or specialized technological solutions to customer needs. This strategy also made it possible to avoid price based competition. Famously, this orientation was underwritten by commitments to skilled labor, cooperative labor relations, and institutional supports for training and technological research. Given the producer orientation to foreign customers, it was long thought that this strategy was compatible with, if not uniquely suited to, international competition's increasingly global character.

As it turns out, the last decade of economic globalization generated significant change in the model's competitive 
strategy and in its underwritten commitments and institutional supports. First, in many sectors (and their supply chains), in particular automobiles and machinery, exporting receded and FDI has emerged as the dominant strategy for accessing many global markets. In the core sectors, more German manufacturing production and employment growth occurred outside Germany than within Germany over the last decade. This was especially the case in large emerging markets like China, but growth occurred in other markets as well, such as North America, Brazil, India and eastern Europe.

Second, in order to compete successfully in those offshore markets, German firms adapted existing products and developed new ones suited specifically to the lower costs and less technologically sophisticated emerging economies. German producers still insert themselves at the higher end of emerging markets, but high quality is a relative and not a natural category. A firm's ability to insulate itself from cost competition is context dependent. As a result, German producers are developing local engineering competence and improving their offshore cost reduction systems to solidify their competitive positions. Thus, purchasing is regionalizing, foreign design and engineering competence is expanding and the formal self-optimizing and cost reduction procedures contained within corporate (Ganzheitliche) production systems are globalizing.

Finally, these changes associated with strategic and production shifts outside Germany have significant consequences for firm strategy, production organization, industrial structure and labor markets inside Germany. German production locations continue to manufacture high quality export goods. Indeed, the same "produce where you sell" logic that leads firms to expand their production and development operations abroad pushes them to retain production and development competences at home. But production character and home location workforce composition is changing significantly. On the one hand, because demand growth in export markets is significantly slower than FDI production growth and home location productivity rates are very high, the home country direct production labor force is shrinking. Skill levels in direct production are increasing, but the number of production workers is declining. On the other hand, driven by the new global internal governance practices (Ganzheitliche Produktionssyteme), home country engineering and design competence is drawn into a support role for far flung MNC technical experimentation processes. Such activities grow along with offshore competence and production sophistication expansion, thus increasing home country production engineer and technician demand. Combined, these two developments generate profound German industrial workforce recomposition, even as absolute levels of industrial employment remain constant.
Additionally, core industrial and labor markets are segmenting. This is a multifaceted phenomenon. The element receiving the most attention in the literature involves temporary work expansion within core firms (Artus 2013; Bosch et al. 2007; Eichorst 2012; Haipeter 2013; Spermann 2011). In order to reduce costs and, most importantly, enhance flexibility in volatile business cycles, manufacturing producers are creating two workforces within home country plants, one permanent, the other on fixed-term contract. Strikingly, this trend is growing even as skill levels secularly increase: though most temporary labor is lower skilled, temporary labor is growing throughout the skill distribution.

Across firms, nearly relentless vertical disintegration over two decades created an organizationally and spatially dispersed production structure (Herrigel 2010). At its most extreme, in the automobile industry, unaffiliated supplier parks, filled with independent component and sub-systems producers, service large assembly complexes. Although often intimately integrated into assembler product development, production and assembly rhythms, these suppliers are located in different political jurisdictions. Moreover, supplier park workers delivering finished components just-intime into the final assembly sequence are organized by a number of different (and competing) trade unions, when they are organized at all. A very "un-German", highly segmented, collective bargaining landscape is emerging as a result.

Finally, segmentation exists within production itself through the re-emergence of capacity-sub-contracting (verlängerte Werkbank). Core automobile, components and machinery producer home location production capacity is overstressed due to the many roles the locations play in their global firms. German plants not only produce for European markets and global high-end export customers, they also perform ongoing product development, process optimization and transfer and prototyping for production locations world-wide. The result is capacity pressure on in-house operations. Companies are unable to accomplish all that they need to with available resources. Unwilling to expand internally, firms outsource even highly sophisticated components and assembly operations to lower-cost firms to unburden their on-going production flows. These subcontractors, in classic verlängerte Werkbank fashion, simply make products according to customer blueprints. They have no in-house engineering or design capability. Their comparative advantage is in small and medium volume production at lower cost with extremely quick turn around between order and delivery. Unlike classic verlängerte Werkbank suppliers, however, these new capacity producers often produce with exactly the same production machinery as their customers, rely extensively on highly trained (if non-unionized and frequently foreign) skilled workers, and cultivate fluency in the complex self-optimizing practices for quality 
Fig. 1 Growth and price forecast. (Source: Economist Intelligence Unit 2011)

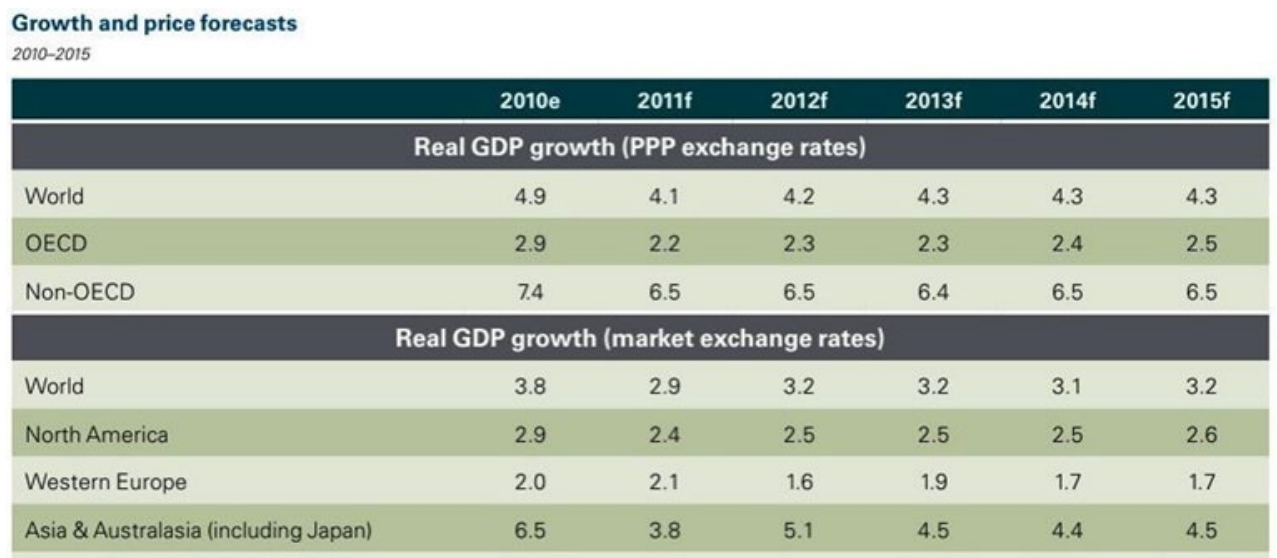

and cost reduction associated with their customers corporate production system procedures.

This article develops each of these aspects of German production model transformation. The first section discusses the strategic shift between exports and offshore production, as well as the new global product strategies and intra- and inter-firm governance practices bound up with it. A second section then discusses the consequences that these shifts have for home country operations and relations. A conclusion reflects on the implications that these developments have for the industrial relations system and industrial policy in Germany. Overall, the take home conceptual message is that contemporary manufacturing globalization processes are recursive: i.e.: actions taken outside of Germany, on all levels, have consequences for-and involve change in - organizations and practices within Germany.

\section{A. Global industrial demand and German manufacturing location: Emerging economies and the shift from exports to "produce where you sell"}

From a developed country manufacturing MNC perspective, global opportunities for growth and expansion have shifted notably in the new century. For most of the twentieth century, the richest markets for manufactured goods were also the largest and fastest growing ones. For German manufacturers, this meant that the bulk of their exports and FDI efforts targeted the developed (western) European, North American and North Asian economies. This geo-economic growth distribution, however, began to change in the last decade. Most forecasting agencies suggest that the new trends are likely to accelerate in the next several decades ${ }^{1}$. For example, the Economist Intelligence Unit (EUI) (2011) expects world real GDP growth to increase approximately $4 \%$ yearly between 2010 and 2015. But the EUI projects

${ }^{1}$ For example, see Bergheim 2005, Trinh 2006, Dyck et al. 2009, Walter 2007.
OECD country growth rates to be only $2 \%$ yearly, while non-OECD annual growth should exceed $7 \%$ for the same time period. A different measure by the same institution shows Asia (including Japan) growing twice as fast as the rest of the world over the same time period (Fig. 1). In the same vein, the German Chamber of Commerce estimates that China will go from having $1 / 3$ of potential middle class consumers as the United States ( 70 to 236 million) in 2001 to having well over twice as many in 2015 (700 to 284 million). ${ }^{2}$ The later number shows that while current trends represent a relative shift in demand expansion, rather than an absolute locational shift, the quantitative levels separating the two markets are narrowing rapidly.

In many specific industrial product areas, from consumer electronics and automobiles to hydro-electric turbines, the contrasting demand situations are quite dramatic. Developed markets have reached saturation points where demand is primarily driven by existing product replacement (when demand expands at all it is doing so in the low single digits), while there is double digit demand growth for the same products in developing Asia or other Brics. In the global electronic and electromechanical industries, for example, Deutsche Bank Research shows that between 1998 and 2007 US and German demand grew less than $2 \%$, while Chinese, Russian, Malaysian and Indonesian demand exceeded $10 \%$ (Fig. 2).

Global machinery and automobile markets exhibit similar imbalances. The German Automobile Association (VDA) notes that developing countries accounted for just $22.3 \%$ of global automobile demand in 2000 , but expects this share to reach $48 \%$ by 2020 (Fig. 3). The picture is very similar in the machinery industry. The German Machinery Association (VDMA) shows that by 2011 China became the world's single largest machinery producing country, selling nearly twice as many machines (of all types) $€ 230$ billion to $€ 563$ billion - as Germany (Fig. 4). Our interviews with a German hydro-electric turbine manufacturer revealed

\footnotetext{
${ }^{2}$ Reinhardt 2009.
} 
Fig. 2 Emerging markets growing faster than developed markets. (Source: Rollwagen and Ranik 2012)

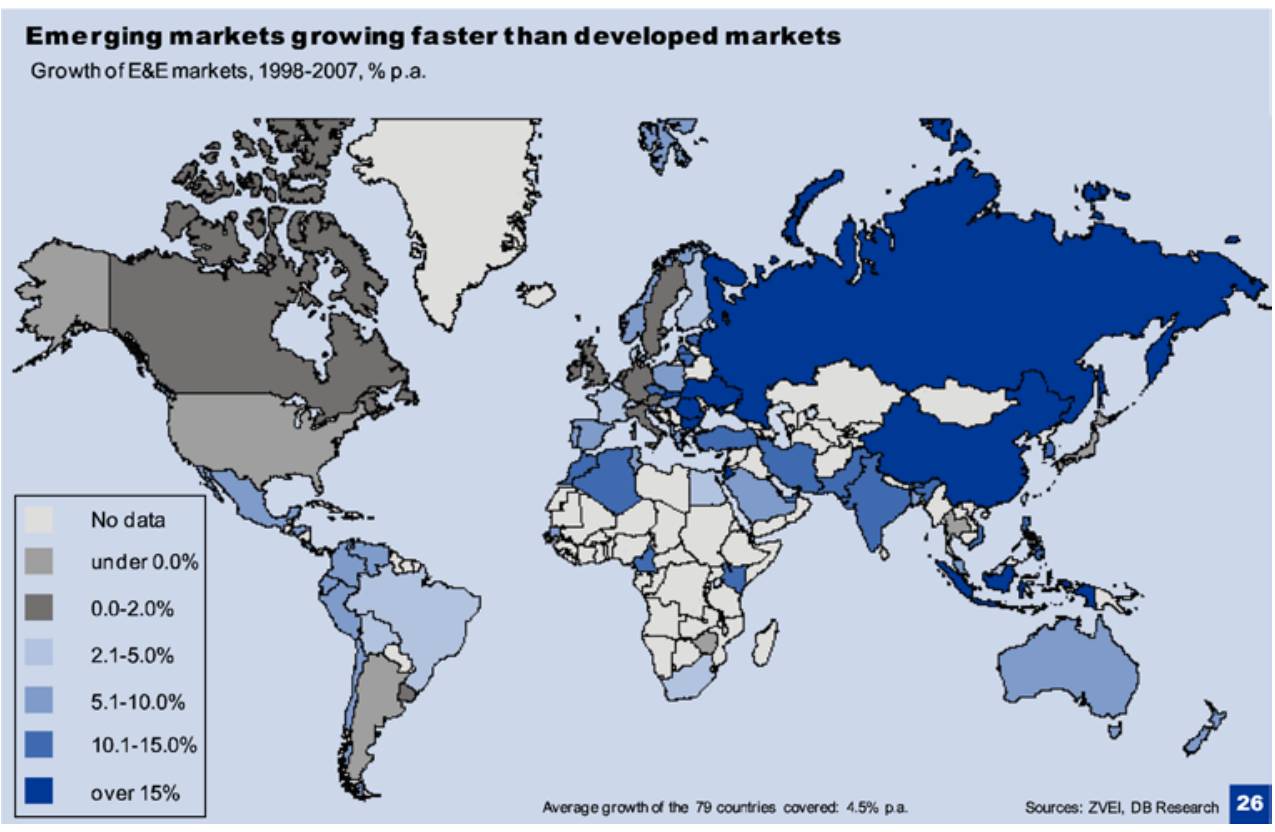

\section{Anteil der Emerging Markets* an der globalen Pkw-Nachfrage (in \%)}

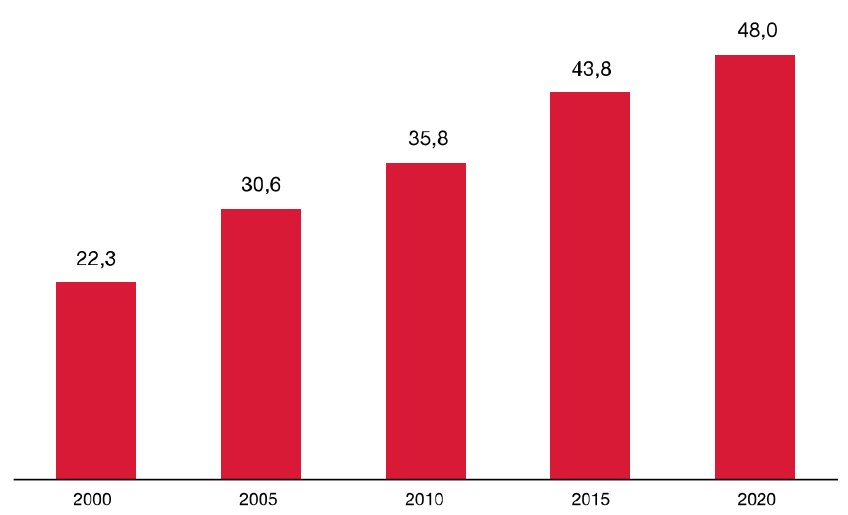

*Schwellenländer mit einem niedrigen oder mittleren Einkommen, aber einer sehr hohen Wachstumsrate, beispielsweise China, Indien, Rumänien oder Bulgarien Quelle: F.A.Z.

Fig. 3 Emerging market share of global passenger car demand

that the company currently only sells replacement parts and components in Europe and North America. All new global demand for turn-key hydro-electric generating complexes comes from Latin America, Asia and Africa. ${ }^{3}$

These very significant relative manufacturing demand shifts are fostering a massive strategic shift in MNC developing economy strategies and, more specifically, in the relative weight of export vs FDI. In short, emerging market demand growth is so rapid, technologically challenging and quantitatively massive that it cannot be serviced through exports alone. Viewed by sector, the shift between export

${ }^{3}$ Hydroelectric power machinery manufacture is one of the cases examined in Herrigel et al. 2014. and FDI within German MNCs is very clear. German automobile producers, for example, currently manufacture more vehicles outside Germany than they produce inside Germany (Fig. 5). By far, the largest offshore production location for German car makers is China, followed by Spain, Brazil, the Czech Republic and Mexico (Fig. 6). ${ }^{4}$

Trends in Machinery production are less pronounced; exports still overwhelm offshore production in most German machinery branches. In part, this stems from many producers' small batch and customization orientation. Home facility capacity can accommodate the quantity and variety of world demand. ${ }^{5}$ But the sector's export direction and FDI trends follow the same general pattern being described here. Emerging markets, especially China, attracted enormous German output and FDI in the last ten years. Take, by way of illustration, the direction of German machine tool exports. In 1984, China took only $1.2 \%$ of total exports, while the US was Germany's largest single country customer, at $11.3 \%$ of exports. By 2011, however, China was Germany's single largest export market, taking $29 \%$ of machine tool exports. The US was second with a comparatively modest $9.1 \%$ share (Fig. 7). FDI trends follow this export shift. While the US still remains the largest German FDI location (with $15.7 \%$ of German machinery FDI in 2006), China's share grew significantly. As late as 2001, China received only $2.1 \%$ of total German machinery FDI, but by 2006 , China had a $5.2 \%$ share. $^{6}$

\footnotetext{
${ }^{4}$ Moavenzadeh 2006.

${ }^{5}$ Fuchs and Kirchain 2010.

${ }^{6}$ Herrigel et al. 2013.
} 
Fig. 4 World machinery sales 2011. (Source: http://www. produktion.de/wp-content/uploads/2012/05/weltmaschinenumsatz-vdma.jpg)
Volkswirtschaft und Statistik

Weltmaschinenumsatz* 2011

TOP-10-Länder-Ranking

in Mrd. Euro

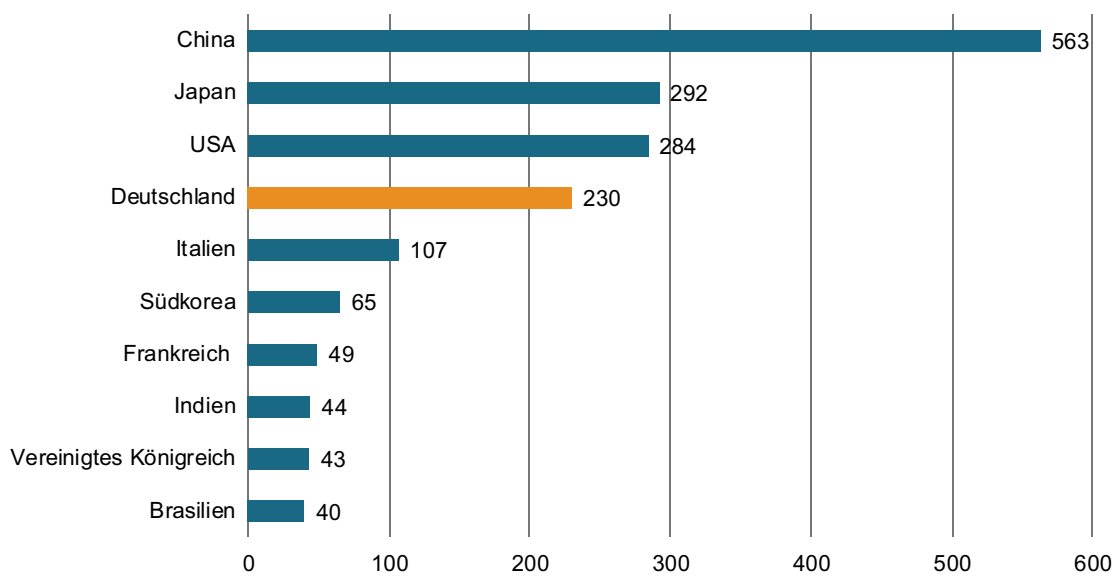

*) Maschinenbau ohne Serviceleistungen wie Installation, Reparatur und Instandhaltung

Internationale Grafiken-Anke Uhlig-Stand: April 2012

\section{Foreign output higher than domestic production Cars produced by German automakers (million)}

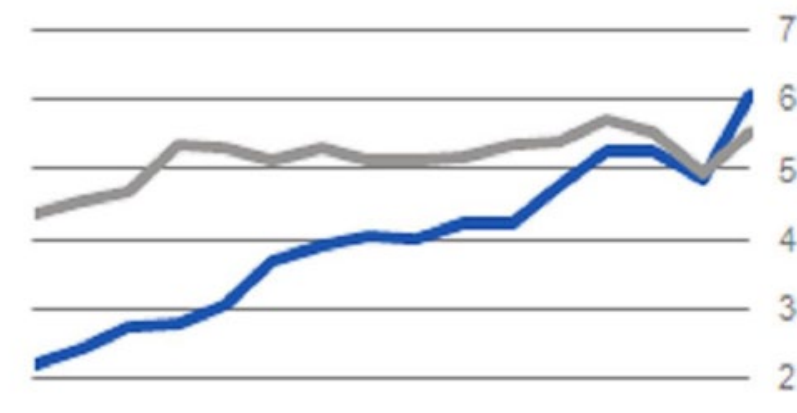

95969798990001020304050607080910

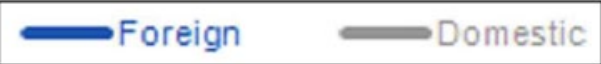

Fig. 5 Foreign output higher than domestic production. (Source: VDA Jahresbericht 2011)

\subsection{Produce where you sell}

The numbers show that German MNCs are trending toward local production in offshore markets rather than relying, as they traditionally have, mainly on exports. This issue is more pressing for the automobile industry than it is for the machinery industry. But as the data on the machine tool industry show, the issue is non-trivial for many machinery producers as well. This shift has to be understood strategically: German MNCs build up design and production competence in important, large foreign markets because they believe that is the best way to gain market share there. This shift should not be viewed, however, as a move to abandon exports as a strategic capability. Exporting ability is a crucial strategic element in a MNC's repertoire enabling it to balance global production capabilities and capacities. Indeed, intra MNC production competence reallocation seems to be re-casting which units export (and to whom) rather than eliminating the practice. In many cases, new MNC production locations in China, Brazil or the US are now just as likely to export their products to third markets as are German and European locations. The mix of local production and export is produced by strategic calculations within MNCs that involve global considerations of cost, capacity and stakeholder interest.

Many strategic concerns involving the relationship between export and offshore production are perennial and familiar, such as the desire to avoid currency unpredictability or tariff discrimination by host country governments (e.g. Caves 2007). But increased offshore investment and upgrading enhances many traditional headaches associated with exporting and introduces additional strategic problems. For example, a major traditional factor working against 
Fig. 6 Offshore production of German passenger cars, by country. (Source: VDA Jahresbericht 2008)

Fig. 7 German machine tool exports: major customer markets. (Source: VDMA 2012)

\section{Auslandsproduktion von deutschen Pkw nach Ländern 2007}

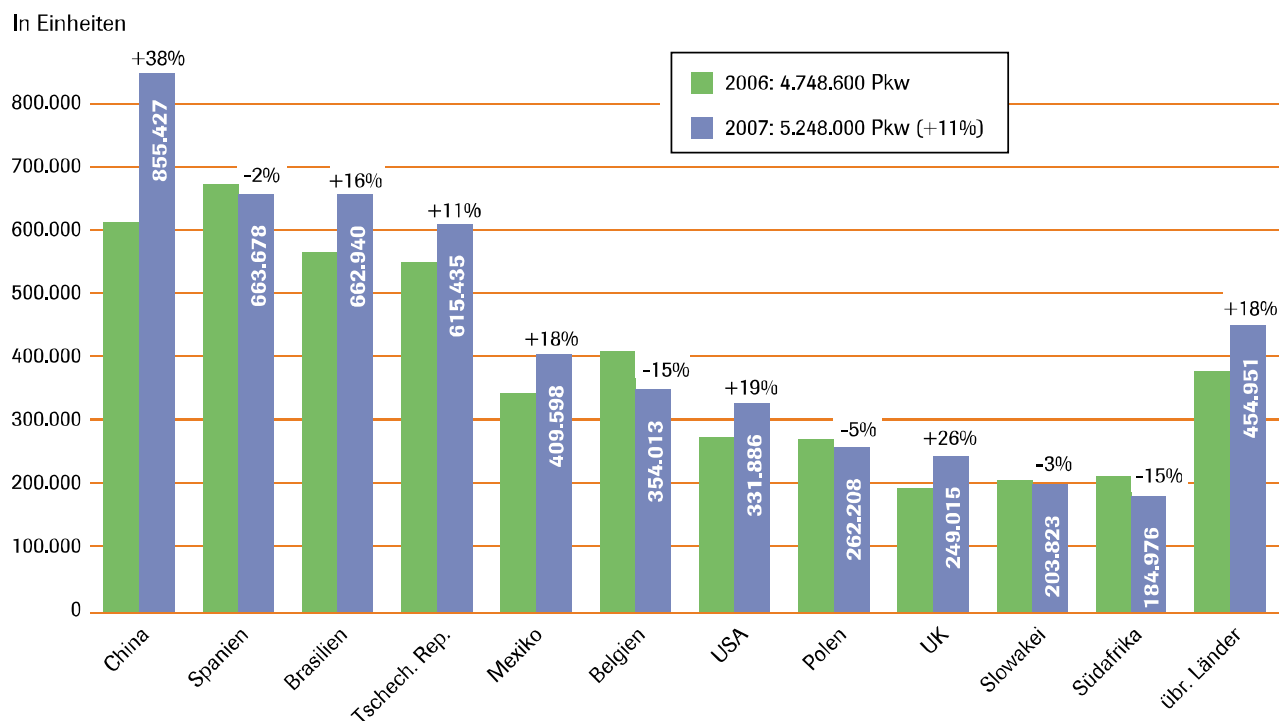

\section{Deutscher Werkzeugmaschinen-Export: wichtigste Absatzmärkte}

German machine tool exports: major customer markets

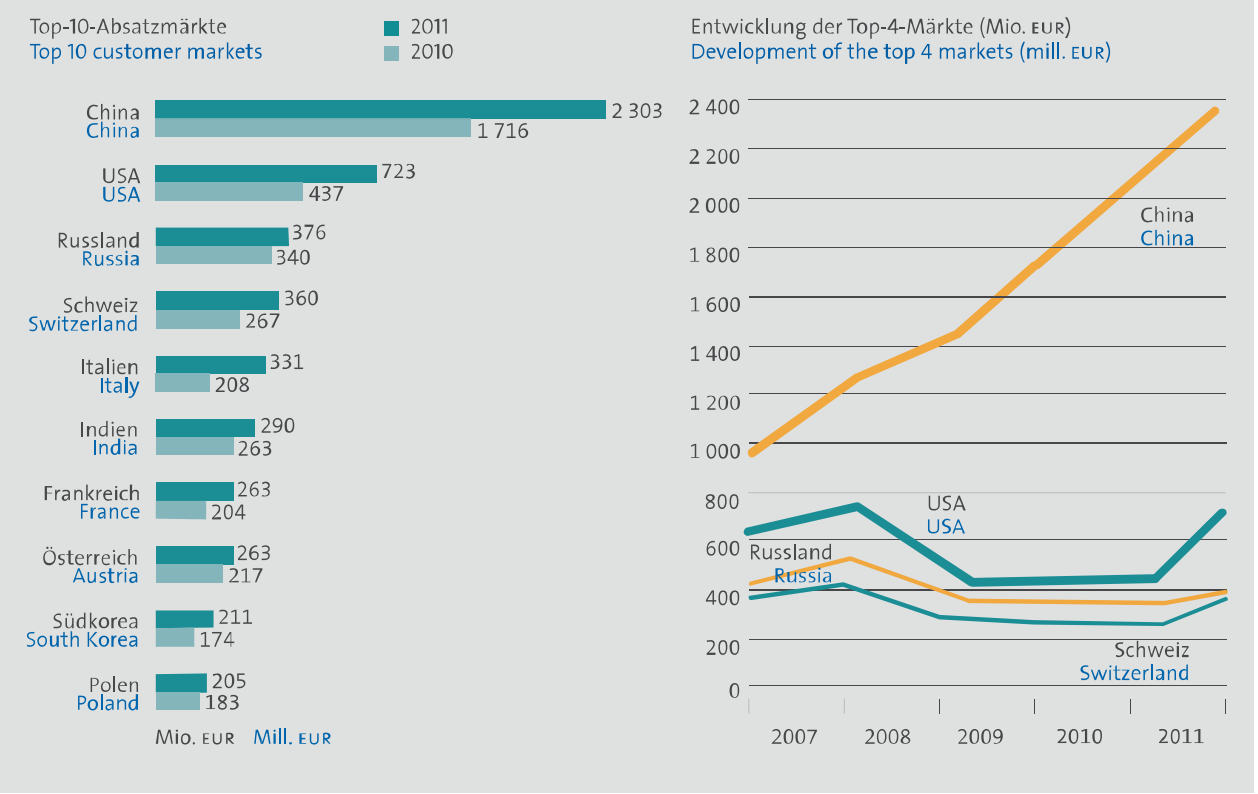

exclusive reliance on exports is receiver market regulations and standards. This problem intensified in recent years as offshore markets became larger and more complex. The more receiver market regulations and standards diverge from the home country's, the more special design and production adjustments are required to make the product "sellable" in a foreign market. The larger the target market, the greater the claim this special attention makes on home location design and production capacity. Beyond a certain volume (which varies by technology, product and receiver country regulations and standards), such adaptations overburden home country operations. As a result, the argument for shifting those investments to the market they are being made for becomes compelling.

Additionally, large offshore and emerging markets have very distinctive consumer cultures with specific product design and performance preferences. The more intractably idiosyncratic market tastes are, and the larger the target market, the more practical and cost effective design and production localization becomes. The "intractability" of local preferences and tastes is especially high when there is intense producer market competition. Firms - other MNC competitors as well as indigenous producers- compete for market share by appealing to local preferences in their prod- 
uct designs. If the market is large and intensely competitive - as it is in China or in the United States - then local design and production is advantageous. Local designers are more familiar with (often rapidly shifting) local preferences than far off German designers are. Local production facilities can adjust more rapidly to product changes and innovations because, unlike the larger home production facilities, they don't have to compete for internal production capacity with lines devoted to other export markets. In this way, local upgrading enhances offshore subsidiary competitiveness.

Localizing design and production operations, finally, are not only strategic responses to regulatory and market factors, they also create strategic advantages. Above all, local design and production capacity facilitates local materials and components sourcing. Automobile and machinery industry material inputs and components outside of Germany are often less expensive and lower in quality than they are in Germany. Since offshore competitors use these inputs in third markets, German producers are pushed to do the same to avoid being priced out of the market- especially in mid-range markets where cost competes with quality in the consumer choice. Adjusting product designs and production processes to accommodate different quality materials and components, however, is most effectively accomplished locally, with designers and purchasing agents familiar with indigenous resource markets. Making such changes nearby also avoids the costly possibility that home country engineers and production personnel might block such changes on the grounds that they degrade the product and violate basic design standards. In short, design and production localization can create strategic advantage in foreign markets by facilitating cost reduction and minimizing internal resistance to change.

Finally, one shouldn't go too far in emphasizing the trend toward "producing where you sell". Localization does not completely eliminate old style export from home market plants as a strategic component within the MNC arsenal. First, the most high-end vehicles in German automobile companies product spectrum are still made in Germany and exported to markets all over the world. This is possible because volumes for any particular market are small and therefore the associated adaptation costs (compliance with local regulations and standards) are not too expensive or too capacity demanding. A similar logic is at work in many machinery sub-sectors. Secondly, in general, for all products, regardless of the value or market segment, whether one exports or shifts production to a foreign market is a cost and available capacity question. If it is possible to service demand in a foreign market with product made in German factories without incurring excessive adaptation costs or over-burdening indigenous production lines, then exporting is preferable to off-shoring and localization.
1.2 Strategic global product development and production shifts

Conceiving of offshore production expansion and export capability retention as strategic tools is not only a departure from traditional German MNC practice. It is also part of a larger global competitive strategy reconceptualization process within MNCs. Traditionally, German firms saw their competitive strength in product quality and technological sophistication. Classically, they avoided price competition by targeting high-end customers or customers with special needs, most of whom were located in highly developed political economies. Now, however, German manufacturers see their advantage differently. Instead of insulating their products from price competition through the production of esoteric and highly specialized technologies, they emphasize the internal and external processual capabilities associated with product development engineering and manufacturing. This enables continuous innovation at a high and ever changing technological level, while simultaneously lowering the overall cost structure. Three factors account for this movement from one strategy to the other.

First, German competitor product quality is improving, making the boundaries with high end products less clear, and hence, competitor products more attractive. Further, German MNC competitors do not simply come from the traditional group of highly developed countries. There are also important emerging market economy competitors. This is especially true in many machinery and automobile component sectors. German producers can still try to leverage their engineering expertise and reputation to stay competitive at the higher end of product markets. But the location of the "high end" is constantly changing. This pressures German players to focus on costs and emphasize constant innovation (c.f. Brandt and Thun 2010; Herrigel et al. 2013, 2014).

Second, the bulk of offshore automobile and machinery market demand is for high quality middle range products. (Herrigel et al. 2013, 2014; Brandt and Thun 2010). Demand for German quality products is modest in the advanced markets and is too small in emerging ones to produce significant growth. German MNC manufacturers believe that if they want to continue to grow, they must become competitive in offshore market segments in which cost and manufacturing quality play a decisive role. Ignoring rapidly growing middle range demand in favor of high value added niche markets both threatens stagnation and creates the possibility that German producers will lose touch with the specific technical and production needs that customers in emerging markets are developing.

Third, global competition fosters innovation by challenging and destabilizing traditional market strategies, firm competences and roles. Often this is portrayed exclusively as a 
high technology phenomenon (Zysman and Breznitz 2012; Berger 2013). Innovation in information technologies, new media, and bio-engineering create whole new industries, challenge traditional firms and elevate new corporate players and new more open practice and governance forms to prominence. As significant as those on-going transformations are, they divert the eye from the turbulent innovation, product and process transformation dynamics occurring in more "traditional" sectors, such as automobiles and machinery. Consider the introduction of micro-electronics, new materials (such as plastics and composite materials) and, most recently, hybrid and other alternative energy technologies in the automobile industry. In order to incorporate these new technologies into their products, firms must quickly re-allocate resources for new competence development. This generates not only acute cost consciousness (devoting resources to future innovation means that actors in the present must make do with less), it also leads to extensive vertical disintegration. Firms move in new directions by hiring and collaborating with outside specialists who work jointly with them to develop new products. They save costs by subcontracting component manufacturing to specialized suppliers who have greater expertise and can more efficiently produce them. Innovation, constant cost reduction and the strategic supply chain enhancement are all of a piece (Herrigel 2010).

Through these shifts in practice, German MNCs dynamically reconceive their competitive advantages. Rather than looking to avoid competition by insulating themselves in high-end niches, German producers now leverage innovation, cost control and supply chains to beat their competition with ever improving products and customer solutions. Competitiveness lies less in the control of a particular technology or product, and much more in a firm's ability to continuously learn and innovate in ways that change the technology and respond to customer desires in a cost competitive way. At the limit, just as it overturns the opposition between offshore production and export, the new strategy also increasingly ignores the distinction between manufacturing and services. German manufacturing MNCs are not merely particular product manufacturers, they are continuously innovative experts in sophisticated (and rapidly changing) areas of technical consumer desire. This latter element drives, in particular, machinery industry emerging market FDI.

\subsection{New MNC governance practices}

These global German MNC strategic product development and production shifts pose significant governance challenges. Firms must optimize exports with global production capacity while simultaneously reconciling constant imperatives for process and product optimization, innovation, cost reduction and learning, not only within individual plants, but also centrally and locally across vast global organizations. This is not easy: innovation can increase costs; optimization and cost reduction can undermine learning; too much local autonomy can generate centrifugal pressures weakening the various forms of leverage (learning, knowledge, purchasing) that come with global concern membership; too much central direction can undermine local innovation and organizational capabilities crucial for competitive advantage in foreign markets. Not only that, global competition is so dynamic that there is never a natural sweet-spot in which all of these competing goals and pressures can be stably reconciled or a happy equilibrium attained. New products, technical innovation, competition among suppliers, new local regulations, currency value shifts, organizational learning induced possibility -and much more - constantly destabilize the ordered practices that firms develop and generate new adjustment and governance challenges. Innovation, cost reduction and learning are imperatives for all actors throughout MNC operations. Yet environmental uncertainty is so great that at any given moment players have no clear sense of what strategy would be most optimal for them to achieve those goals.

In this context, traditional top down principal-agent management practices do not work. They rely on the ability of higher-level management to set effective strategy and provide lower-level actors with clear incentives to fulfill tasks. In the current continuously changing environment, however, higher-level management does not have sufficient knowledge of lower-level conditions to create effective incentives. Moreover, actors at lower levels are faced with unpredictable destabilizations on their terrain which affect their roles and interests in ways that make centrally imposed incentives either irrelevant or counter productive. In response, firms are abandoning these hierarchical arrangements for more mutually dependent and cooperative arrangements between central and local players that allow for continuous organizational self-recomposition.

The logic of the new governance forms is best illustrated by the widely proliferating formalized "experimentalist" systems, such as corporate (Ganzheitliche) production systems (CPSs). ${ }^{7}$ CPSs are formal systems that organize group or stakeholder based goal setting within firms to achieve product and process innovation, optimization (cost reduction) and learning on a continuous basis. ${ }^{8}$ The systems are

\footnotetext{
${ }^{7}$ See Sabel and Zeitlin 2012; Sabel and Simon 2011 for a discussion of experimentalist architectures. Virtually all large firms investigated in Herrigel et al.'s (2014) study of automobile and machinery producers had their own CPSs. Each branded their CPS (e.g. The Siemens Production System or "The Volkswagen Way"). Smaller companies also embraced the formal experimentalist team governed lean production principles even though many did not attempt to "brand" their system.

${ }^{8}$ CPSs are part of a family of formal practices (which they often also incorporate), such as six sigma programs and other formal open stan-
} 
rooted in team goal setting procedures (regular goal setting meetings) and constitute a hierarchical architecture of team based goal conversations, ultimately linking (through many mediations) the shop floor to the top management. The conversations are also systematically cross-functional-in the best systems, cross-functionality runs throughout the firm, from the shop floor to top executive suites. And, crucially for the story here, the team conversations are global. Product, customer, design and manufacturing, and continuous improvement teams all are constituted in multiple locations and form super-ordinate or umbrella teams that engage with one another across markets and geographical space to identify common goals and standards. Local experiments are continuously and openly compared (and defended).

The following example, reconstructed from interviews at a German Truck and Omnibus transmission producer, illustrates the globally recursive and learning elements of these systems. ${ }^{9}$ The process begins with joint German design and manufacturing teams in South Germany developing a new variant of a medium sized transmission for the global market. Technical specifications, cost targets, and manufacturing time are worked out in an iterative process of experimentation and exchange between design and manufacturing engineers, the prototyping workshop and the home location shop floor. Conversations between this product team and a higher-level global strategy team, very early on, suggest that the transmission will also be produced in China, Russia, India and other emerging markets. Design and manufacturing teams from these markets are incorporated into the development process and technical specifications, cost targets and manufacturing cycle parameters (metrics and standards) for those markets are provisionally established.

We followed the transfer of the technology to the Chinese markets. German design and manufacturing engineers, as well as skilled workers from the proto-type workshop and home location shop floor, travel to China to assist local engineers and workers with the initial production set up. Local Chinese engineers educate their skeptical German counterparts about the Chinese location's possibilities and limits. Adjustments along several dimensions are made locally, involving a variety of metrics and standards on input materials, contour design, machine usage and cycle time. Engineers from the transmission producer's Chinese design center are called in to assist the collaborating teams with these adjustments. Design and production metrics and standards are altered, so the German design office is consulted to approve suggested changes to the original targets.

dards systems (e.g. ISO certifications). See Sabel 2005, Spear 2009, Friedli and Schuh 2013, Heil et al. 2013, Gerst 2010, 2011, for general discussions; for a description of the development of a CPS at Daimler, see Clarke 2005.

${ }^{9}$ This example is taken from Herrigel et al. 2014.
The local production and design teams defend the changes to the central teams. In the process, the central team notices that the adjustments in manufacturing flow can be used for the same product in eastern European and in Indian production locations. Changes are made to the central design. Production performance both in Germany and in offshore locations is, in this systematic fashion, regularly reviewed, metrics and standards are optimized, and roles and relations recomposed.

All of this iterated transfer and exchange occurs within the company's CPS language and team based procedures, which requires regular goal setting and performance review meetings. CPSs insist on explicit, written down, metric and standards specification. Significantly, stakeholder teams working with agreed upon metrics and standards drive each step in this development and transfer process. The jointly defined standards and metrics serve as benchmarks for local experimentation. Iterated revision, guided by the formal metrics, characterizes the entire process. Transnational know-how transfer and experience driven learning, facilitated by team interactions, are systematic features of this system. There is, moreover, recursivity in the system as the central (Germany based) teams learn from local (China based) team experiments, even as the latter are learning from the former. Finally, metric and standards revision involves organizational role and rule changes. Design and production labor allocation is continuously optimized and varied. Stakeholder interests are not aligned by the system, they are continuously changed through metric and standard creation, performance review and optimization processes. ${ }^{10}$

These CPS dynamics pervade contemporary global corporate behavior, across a remarkable array of sectors. The new governance forms identify possibilities for learning and innovation and diffuse discoveries throughout the global firm. German producers regard such governance skills as a competitive advantage (Friedli and Schuh 2013; Heil et al. 2013).

\section{German MNCs, recursivity and the home economy}

This section examines the consequences for home country locations of the strategic shifts and recursive global governance dynamics discussed above. We look at home country processes both internal and external to the MNC. For example, how are German home employment and workforce skill composition affected by the emergent compe-

\footnotetext{
${ }^{10}$ Our own research in the machinery and automobile industries, as well as parallel efforts in the literature, suggest that German and American firms are more tolerant of local discretion and hybridization than are their Japanese counterparts, although all deploy rigorous corporate production system techniques. Herrigel et al. 2013, Speed 2007, Jürgens and Krzywdzinski 2012.
} 
tences offshore? How is the global role of the home location changing? How are global experimentalist governance systems affecting home country arrangements in industrial relations, training and regional and industrial policy? What, in other words, is at stake within Germany in manufacturing globalization?

We argue that the recursive consequences for German locations from MNC global activities are profound. German manufacturers and the social and political home context in which they operate have slowly been recomposed through their practical engagement in global markets and with their emerging market interlocutors. Adjustments in workforce composition, role definition, design and production processes, and in the configuration of extra-firm governance and service relations are taking place.

Much of the literature on Germany and neoliberal globalization focuses on growing segmentation and on the concessions that core workers in competitive firms have made to protect their jobs (Bosch et al. 2007; Eichhorst 2012; Hassel 2011; Spermann 2011; Thelen and Palier 2010). This literature, however, emphasizes the changes outside the traditional structures of full time production work within firms: In particular, it focuses on the emergence of lower paid, part time, temporary, and precarious workers within firms, industries and in the core labor market. As important as these developments undeniably are, the literature either ignores or mischaracterizes developments that are occurring within the so-called core governance and production arrangements in the German political economy. Views either overly pessimistically lament the inescapable decline of German trade unions and traditional German skilled labor based production in the face of globalization induced marketization of all relations, or they over optimistically suggests that the old arrangements, aside from concessions on wages and temporary labor, remain more or less functionally in tact.

By contrast, we argue that there are very real changes occurring inside the core permanently employed high skill sections of globally competitive German firms and across their supply chains. ${ }^{11}$ Governance practices and role, skill and competence allocation are all changing dramatically and in ways that have little to do with "marketization", and go well beyond temporary employment expansion. In any case, the new practices have little resemblance to the kinds of workplace and management structures that characterized competitive German firms even 10 years ago. They pose significant challenges to industrial relations stakeholders and to broader German industrial, research and educational policy players.

\footnotetext{
${ }^{11}$ For parallel critiques of the above literature, with an emphasis on core wage concessions, see Baccaro and Benassi 2014, and with an emphasis on the growing fragmentation of wage and contractual schemes within the core see Holst 2014
}

This section proceeds in two steps. First we show that the strategic shifts and governance changes discussed above effect less the quantity of employment in German manufacturing than the quality of employment that has emerged. Workforce competence composition and role allocation within German production locations is profoundly changing. Second, we show that this competence recomposition also involves significant segmentation, not only in labor markets, but in production itself.

2.1 Competence recalibration rather than employment reduction in auto and machinery industries and their supply chains

The interconnected global relations driving contemporary German manufacturing are far more likely to generate workforce skill recomposition in German locations than they are to result in employment loss. Of course, in general, manufacturing employment has been declining in all advanced political economies. But this seems to be attributable to factors other than the expansion of MNC FDI offshore. ${ }^{12}$ As Dorn and others have shown, even in the United States, where manufacturing has been much more dramatically affected than in Germany, the bulk of manufacturing employment decline has come from two major factors, neither of which are associated with MNC FDI or changing production strategies: First, sectors that compete directly with low cost imports, especially those coming from China (or CEE in the German case), have been unable to remain competitive and have sustained severe employment losses. These are largely lower tech industries, such as clothing, furniture making, and other lower value added segments or processes within a variety of industries. A second significant factor in the manufacturing employment shift in the United States, and to a large extent in Germany as well, is continuous manufacturing productivity increases. The diffusion of lean production practices, coupled with CPS development and automation elevates manufacturing productivity rates well above the productivity growth rate in the economy as a whole. ${ }^{13}$

\footnotetext{
${ }^{12}$ Dorn et al. 2011, Ebenstein et al. 2011, Harrison and McMillan 2011, Spence and Hlatshwayo 2011.

${ }^{13}$ Slaughter 2012, McKinsey Operations Practice 2012. There is some debate, especially in the United States, on how much low-cost inputs, traveling along transnational supply networks, have contributed to productivity increases in manufacturing. Surely it has had an effect, perhaps more in the US than in Europe (Mandel and Housman 2011). Intermediate inputs in the US come significantly from lower wage locations, especially China, while intermediate inputs in Europe often tend to come from central Europe.(European Commission 2012) In any case, new studies show that indigenous improvements have been significant. (Harrison and McMillan 2011; Ebenstein et al. 2011; Slaughter 2012; McKinsey Operations Practice 2012).
} 
Rather than affecting home market employment levels the interconnected global production described above is affecting the composition of the home country work force and the role that home country locations play in MNCs global processes. These recursive effects are most characteristic of the interconnected global production strategies MNCs pursue in non-European markets. There the threat of offshore locations being combined with pure capacity outsourcing (verlängerte Werkbank) practices, as was sometimes the case (especially in the early years) in CEE, is minimal. Non-European operations in the automobile and machinery industries replicate and expand European capacity rather than replace it.

Global recursive dynamics in both product and process innovation drive MNC home location recomposition. Take new product development and design functions within the MNC first. Home location centrality for future oriented R\&D for all global product markets is both solidifying and expanding in scope. It is solidifying because home locations have a comparative advantage for engineering talent and contact with research and development infrastructure and support: Universities and polytechnics, pools of highly qualified engineering graduates, and talented clusters of dedicated research firms and consultancies. The home market product development research role is also expanding to accommodate the rapid development and proliferation of product applications and modifications occurring across an unprecedented array of global markets. Central R\&D participates at various levels in product development teams, and collaborates with engineering and manufacturing counterparts in all global locations. As R\&D, design and product development efforts expand in offshore affiliates, the qualitative and quantitative demands on central competence increase correspondingly. Firms need to expand their home location engineering workforce to accommodate this new demand.

Second, at the process innovation level, driven by the new internal governance practices noted in the previous section, home country engineering and technician competence is drawn in to a support role for far flung MNC technical experimentation and adaptation processes. Engineers in subsidiaries all over the world call on home country competence for aid and input in their local experiments on product adaptation and on manufacturing process implementation. Manufacturing MNCs have, as a result, created globally mobile cohorts of engineers and technicians, based in the home locations, with close ties to $R \& D$ engineering expertise, who both cooperate with and monitor the progress and needs of subsidiary product development, adaptation and implementation processes. Many German machinery and automobile component producers, for example, have created continuous improvement teams (CITs) composed of engineers and technicians who travel across all MNC affiliates spreading their company's CPS gospel. CIT's encourage teams to experiment locally, offer improvement suggestions, while at the same time teaching locals how to justify and communicate their adaptations (in the language of the CPS) to the rest of the firm's global community of players. In other words, CITs foster the local discretionhybridization-trans-locational learning dynamic described earlier. (see Herrigel et al. 2014). Significantly, these roles are growing along with the expansion of competence and production sophistication abroad.

There is broad statistical support for the trends toward increased demand for engineers and technicians in the automotive, machinery, electro-mechanical and components sectors. ${ }^{14}$ Movement in the automobile industry-which is European wide - can be used to illustrate the broader trend. While direct production employment at German automobile and supplier firms has remained constant since 2007, for example, research related employment has been increasing dramatically. Automobile producers and their suppliers now account for a third of all German R\&D expenditures. In 2012 , the VDA reported that 89,000 people were employed in research and development jobs in the industry (final assemblers and suppliers), over 2000 more than had been employed in those functions in 2007, prior to the onset of the global financial crisis (VDA 2008, p. 22). This interesting globalization induced labor market recomposition process raises the possibility that home country manufacturing locations will retain their traditionally high employment numbers. Indeed, home country automobile and machinery industry employment could gradually expand in size. But if the current global MNC recomposition processes continue, this employment will have a dramatically different role and

Employment in automotive industry by occupation, 1995, 2000, 2006 口Skilled workers $\square$ Engineers aManagers and other professionals

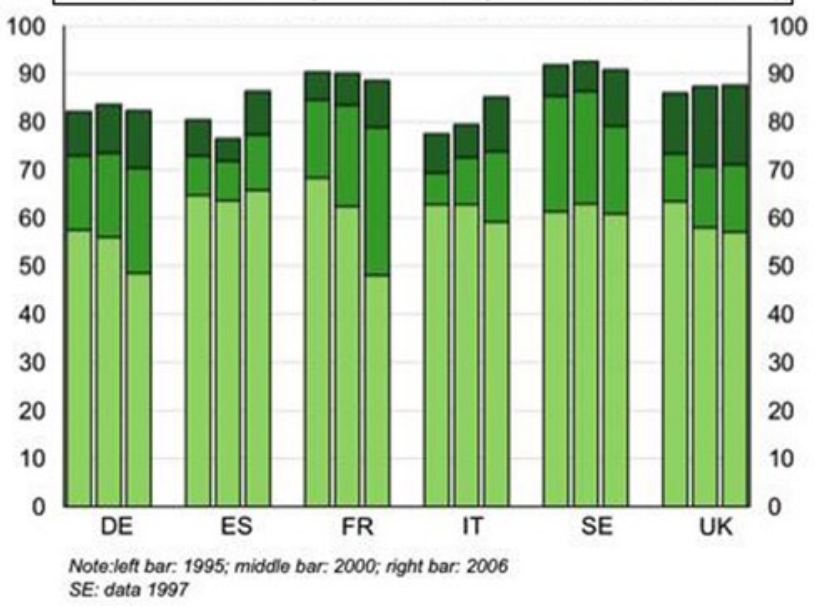

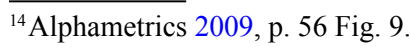


competence distribution than has traditionally been true of manufacturing locations.

\subsection{Continued importance of home production, core segmentation and the return of home grown capacity outsourcing}

The second recompostion dynamic in manufacturing $\mathrm{MNC}$ home locations involves direct production operations. As we just saw, manufacturing upgrading and capacity development in offshore markets has NOT resulted in a loss of either competence or capacity in home market locations. ${ }^{15}$ Instead, current developments point to the retention, recomposition and even upgrading of core manufacturing sectors (automobiles, machinery, components, electro-mechanical machinery). The key here is that the same competition driven "produce where you sell" logic that leads firms to expand their production and development operations abroad also leads them to retain and upgrade production and development competences at home. Home country locations need to adapt their products and designs to local regulations, standards and the idiosyncracies of consumer taste and product usage, just as affiliates abroad do. German firms require sophisticated and flexible manufacturing operations in their home regional complexes in order to competitively serve those markets. Developed country manufacturing markets are growing more slowly than developing country markets. But they are still growing, and, moreover, the character of demand is extremely sophisticated. This stems in part from the advanced and cosmopolitan consumers in these markets. But it also is driven by the fact that firms can only achieve growth in these nearly saturated contexts through innovation. Firms need to define new consumer desires by pushing their products' technological boundaries.

If one combines the reality of innovation driven manufacturing growth with the enhanced role of R\&D in German MNC home operations due to the diffusion of "produce where your sell" strategies abroad, there are a number of consequences for production organization and skill. First, since all signs suggest that competition in developed country markets will become more not less innovation intensive, the productivity enhancing techniques that drove production organization in the last decade are likely only to intensify. This means that the CPS governed emphasis on lean organization, continuous improvement, vertical disintegration and high automation levels will continue to define German manufacturing best practice. ${ }^{16}$ This will constrain the growth of manufacturing workforces. But it will also increase the importance of skilled production work. Manufacturing personnel will be skilled, capable of problem solving, able to

\footnotetext{
${ }^{15}$ European Commission 2011.

${ }^{16}$ see Herrigel 2010 Chap. 5 for overview of those trends in the 2000s.
}

embrace new tasks and be willing to receive on-going training for eventual new roles. ${ }^{17}$

Second, and in the same direction, expanding home country $R \& D$ operations increases the need for home location prototyping, small batch and quick turnaround manufacturing capacity. This further stimulates demand for skilled production labor and technicians. Third, and perhaps most interestingly, the above developments create intense pressure on in-house capacity within MNC home manufacturing plants. Highly skilled labor (in R\&D and production) and expensive automation equipment means that firms want to produce only the most high value added items in-house and do not want to devote capacity to older items, even when those items are sophisticated and headed for home country markets. Moreover, given accelerating product life cycles and the heterogeneity and complexity of new global products being processed within a home market plant, the time separating new and old products can be short. All of this induces capacity strain and leads firms to look for outside suppliers capable of taking over some of the market ready product capacity to free internal workshops for higher end research and proto-type driven experimentation.

In effect, this globalization induced dynamic generates a return to capacity or "verlängerte Werkbank" contracting inside Germany. Unlike the new forms of collaborative subcontracting that emerged over the course of the last twenty years (Herrigel 2010, Chap. 5), this new capacity subcontracting does not involve joint component development or collaborative exploration for cost reduction possibilities. It is simply a relief valve for internal workshops to enable the latter to engage in specialized work. Indeed, many firms insist that these new suppliers use the same machinery and same dies as the internal operations do. In some cases they provide the suppliers with the equipment; in many other cases, they seek out suppliers who already use the same equipment that internal workshops use (e.g. Heller Machining Centers or Liebherr Lathes). The outsourcing firms in these cases do not expect that the supplier firms will have the same skilled worker allocation that their own workshops have. The workers at suppliers must only produce existing products efficiently, while workers in internal workshops must work with development engineers on new product development. As a result, outsourcing firms look for competent suppliers with a narrower skill base and, crucially, with a lower cost structure, especially lower wages.

Since 1989, German firms have "traditionally" turned to CEE suppliers for this special mix of competent work forces at significantly lower wage levels. This practice runs up against two obstacles, however, that leads to the proliferation of new lower wage, capacity-subcontractors inside Germany. First, CEE upgrading and capacity growth over

\footnotetext{
${ }^{17}$ EIU 2011; Graham 2010.
} 
the last decade winnowed out the number of firms with an interest in engaging in this less challenging contracting. CEE suppliers moved up the value chain and engage customers, both in Germany and in CEE, in more creative and collaborative forms of sub-contracting. Second, due to shortening automobile product and component life cycles, as well as the unpredictability of demand for internal capacity, the new capacity suppliers need to be rapidly responsive to customer needs and be in a position to fulfill orders with a very quick turnaround. This disadvantages CEE suppliers, simply because their greater distance from internal workshops creates the potential for delay, miscommunication and additional cost.

Entrepreneurial would-be German capacity suppliers see this situation as an opportunity to gain home market business. Such firms are typically not members of their local Employer Association and, as a result, are not bound to pay the collectively bargained wages or abide by other collectively agreed upon conditions that employer association member firms negotiate with trade unions. These firms hire older skilled workers who have been made redundant in their customer firm operations. They then supplement these workers with immigrant labor that they are able to draw on from eastern and southern Europe. One supplier we visited, for example, had a robust mixture of Italian, Greek, Polish and Ukranian personnel. The immigrant mix can vary; the point is that these firms offer German customers reliable local capacity subcontracting service without any of the distance induced unpredictability and cost of CEE rivals. Interestingly, this shift in home country production location needs and CEE supplier competitiveness is leading to a revival of traditional German capacity sub-contracting regions, such as the Schwaebische Alb, (e.g. Albstadt), or the traditional small producer metalworking areas south and east of the Ruhr (Bergisches Land, Sauerland, Siegerland). Though these regions have long traditions in capacity outsourcing (Herrigel 1995), the new emerging suppliers there constitute new terrain in the contemporary German manufacturing landscape.

\section{Conclusion: Recursive dynamics, institutional recomposition and the emergence of a new German industrial model}

German MNCs global CPS adoption, globalization induced internal shifts in competence allocation and new lower wage capacity subcontractors inside Germany all pose interesting challenges for the German co-determination and industrial relations systems, on the one hand, and for regional and national industrial policy players on the other. Take first co-determination and industrial relations. In the large firms Herrigel et al. (2014) studied, the degree of works coun- cil involvement in the CPS system varied significantly. The large south German Truck and Omnibus Transmission producer had the most elaborate works council integration model. The company established an independent and whole concern agreement with the works council that mandated works council participation in relevant stakeholder teams. In other words, works council social and training expertise was directly solicited in the team deliberations within the firm regarding process optimization, product development, knowledge transfer, and recursive competence shifts induced by globalization. Similarly, at a Southwest German power drive manufacturer, a CIT team pioneer, CIT team members were active participants in the company works council, and the works council was a stakeholder in numerous CPS structured deliberation processes involving product development and production optimization.

In other cases, however, labor and management regarded the newly emerging experimentalist practices as separate from and even incompatible with traditional co-determination arrangements. At a large electrical engineering MNC at which we examined both electrical power drive and electronic controller production locations, works councils were not formally integrated in to the company CPS. As a result, works councils somewhat awkwardly negotiated about decisions that many of those they represented participated in making. The MNC's management, never a works council or the German Union enthusiast to begin with, viewed the CPS as a way to run around the old system. The Works council, quite accurately, viewed the system at a minimum as an unnecessary marginalization of Works council competences in social and wage payment issues. In a larger light, the CPS was viewed as a threat. Such struggles destabilize experimentalist governance processes, and, in the case of the electric power drives division, resulted in works council discontent and foot-dragging regarding recursive competence re-allocation efforts stemming from the upgrading and expansion of the company's facility in Tianjin.

Our impression (Herrigel et al. 2014) is that the above variation is representative of German practice. That is, systems in place vary location by location. While the IG Metall devotes resources and energy to advising works councils about how to positively influence the implementation of CPSs, the efforts are in their relative infancy. The union itself is still divided about CPSs, with many viewing the new systems not as formal experimentalist architectures, but rather as a sort of Japanese version of Taylorism in which stakeholder input is regarded as worker cooptation and speed up (see Hans Boeckler Stiftung 2014; Gerst 2010, 2011). Given the positive experience in locations, such as the transmission manufacturer, where CPSs have in effect expanded the co-determination ideal by recasting it as experimentalism, it seems clear that IG Metall would benefit from systematic 
thought about the conditions under which empowering outcomes can be fostered and cooptative ones diverted.

But as we saw above, CPSs are not the only challenges confronting the traditional system of industrial relations. The gradual manufacturing workforce shift away from direct production workers to a larger engineering and service personnel percentage is also a difficult problem for Unions. Traditionally, direct production workers were the union's core membership, while engineers were more difficult to recruit. There was a perception of a class divide between the roles. Given present competence re-allocation, the Unions must either resign themselves to minority representative organizations within differently structured but still robust manufacturing environments, or re-position themselves so that they are able to address the needs of the new workforce majority. This issue is quite distinct from the question of how the Unionized workforce within firms should relate to the growing number of temporary workers, where, despite the challenges, there seems to have been significant progress (Schmalz and Dörre 2013).

The emergence of new capacity sub-contractors constitutes yet another, and quite different challenge for the trade unions. Here the dilemma is also two sided. On the one hand, such firms are clear affronts to the existing collective bargaining system that gives Unions social and economic power and that still governs labor markets in most large manufacturing firms. On the other hand, such firms are creating direct production manufacturing jobs in Germany. Blocking their proliferation is likely simply to force MNCs to turn back to CEE suppliers. IG Metall, understandably, does not want to be held responsible for the elimination of German jobs. In our discussions with IG Metall leaders in southwest Germany, the general strategy was to work hard to create communication channels between the union and new capacity contractors. The Union accepted the new firms' wage payment practices, but urged the new employers to embrace work-time and other social arrangements that benefitted workers without affecting productivity or cost. (IG Metall Interview) The Union also urged those employers to participate in other, non-collective bargaining related, regional governance discussions among local associations. Thus, in Neckarsulm, for example, suppliers that were not part of the collective bargaining system nonetheless participated in regional industrial policy discussions with industry associations, chambers of commerce, local politicians and the trade unions over future labor market, training and educational challenges confronting the region. If these compensatory efforts save the German industrial relations system, they will do so by transforming its scope.

Questions of scope bedevil Union strategy in other ways as well. For reasons alluded to above vertical disintegration in manufacturing has progressed so far and has become so differentiated over the course of the last two decades, that it has gradually transformed the labor market bargaining terrain upon which Unions must maneuver. ${ }^{18}$ Most pressing for German Unions is the emergence of Multi-Union bargaining units, both within core firms themselves and along the supply chain. Within automobile, component, electro-technical and machinery firms, agreements between Unions and temporary employment agencies govern the wages and working conditions of large segments of employees. These agreements run alongside the "normal" agreements that have been struck between IG Metall and the Employer Association determining core worker wages and working conditions. Multiple Union/ multiple agreement environments are even more rife in the many supplier parks that have sprung up around large automobile assembly facilities. Suppliers perform many operations once done in-house, and the suppliers come from different industrial and service sectors. Workers in supplier parks are covered by multiple agreements between several Unions and employers associations (IG Metall, Ver.di, I.G. Chemie - etc). Obviously, this kind of intra supply-chain segmentation poses extremely challenging (and largely unprecedented) coordination problems for Unions, Employers Associations and, in general, the traditional German system of industrial relations.

Finally, discussion of industrial policy adjustment is appropriate here as well. Germany as a manufacturing location, as well as the regions that host German MNC home production facilities, are directly affected by the recursive transformations generated by globalization. Germans generally take a stakeholder and associative approach to the delivery of supportive policies to industry and to the labor market (Haipeter). The dilemma in the current situation is not so much that this traditional approach is inadequate as it is that the traditional stakeholders and associations are changing: Entirely new actors are emerging and old actors are being recomposed. All confront quite new kinds of challenges. New actors include the new capacity subcontractors who act outside the traditional employer associational structure. Other new actors are the large numbers of engineers and globally active service employees being drawn into German locations. Neither conventionally "workers" nor management, this potentially very crucial element within the future workforce lacks a coherent organization to enact its public face in associational deliberations (including collective bargaining and works council activities). As noted above, Trade Unions are in an awkward position relative to this emerging cohort. They have defined themselves as defenders of direct production workers jobs. It is not clear how the Union will be able to square the circle of supporting its traditional membership while at the same time adjusting to the shifting stakeholder terrain in the globalized political economy.

\footnotetext{
${ }^{18}$ see also Herrigel 2010 and Holst 2014.
} 
In many ways the dynamics described here are "market" driven, in the sense that German MNCs are adopting the described strategies in response to developments in their markets and not at the immediate behest of government policy. This is not to say that government policy could not helpfully influence the recomposition processes described. Since all developed country manufacturing MNCs are struggling to make their offshore operations competitive, it is reasonable to assume that not all will succeed. Success ultimately depends on three interdependent functions: (a) the development of flexible operations and innovative products in emerging markets; (b) the development of effective global intra-firm governance structures and new internal firm players, such as CITs, that carry and distribute innovation and best practice within the global firm; and (c) effective home country R\&D, new product development and global support services that contribute to the continued long term competitiveness of the firm's global operations. Home country public policy can do little to directly influence the competitiveness of MNC products in emerging markets. But it is possible for public support to encourage the development of the other two functions. In particular, public policy can support closer relations between MNC manufacturers and training institutions so that the appropriate forms of manpower are being generated.

The dynamic quality of the current situation, in particular the way in which continuous innovation strategies are generating new roles both within and outside manufacturing MNCs, poses distinctive challenges for public labor market and training policies. Innovation driven flexibility and role recomposition invariably cause disruption in the individual careers of even the most skilled engineers and technicians. Technological advances challenge working professionals to keep up to date, while innovation induced firm re-orientation can cause highly skilled engineers to suddenly look for another employer. This turbulence could be partially accommodated by an appropriately robust infrastructure for retraining and job re-allocation. Such a system would most optimally involve stakeholder organizations - professional and Trade Union organizations representing engineers and skilled workers and technicians, regional and national Employers Associations, and training institutions at all levels - in appropriate retraining and reallocation measures. ${ }^{19}$ The process of addressing these sorts of problems will undoubtedly push the German industrial model even further away from traditional practices.

\section{Executive Summary}

Das deutsche Modell der Industrieproduktion befindet sich wegen der Globalisierung im Wandel. Traditionell konzen-

\footnotetext{
${ }^{19}$ Much in the manner of the Danish Flexicurity system. See Kristensen and Lilja 2010; Sabel 2012.
}

trierten sich deutsche Hersteller vorrangig auf den Export, positionierten sich im oberen, qualitativ hochwertigen Segment des Weltmarktes und vermieden Preiskämpfe. Bekanntlich wurde diese Ausrichtung untermauert durch das Bekenntnis zu qualifizierten Arbeitskräften, kooperative Arbeitsbeziehungen und durch institutionelle Unterstützung von Aus- und Weiterbildung sowie von technologischer Forschung. Lange glaubte man, dass diese Strategie mit dem zunehmend globalisierten Charakter des internationalen Wettbewerbs vereinbar, wenn nicht sogar auf einzigartige Weise dafür geeignet sei.

Im vergangenen Jahrzehnt führte die Globalisierung der Wirtschaft zu entscheidenden Veränderungen in allen Aspekten des deutschen Modells. Erstens ging der Export in vielen Sektoren, insbesondere in der Automobil- und Maschinenbaubranche zurück, und Direktinvestitionen im Ausland entwickelten sich zur vorherrschenden Strategie für die Erschließung vieler globaler Märkte. In den Kernsektoren wurde außerhalb Deutschlands im vergangenen Jahrzehnt mehr hergestellt und produziert und mehr Arbeitsplätze geschaffen als in Deutschland. Dies war insbesondere in großen Emerging Markets wie China der Fall.

Zweitens nahmen deutsche Unternehmen Anpassungen ihrer bestehenden Produkte vor und entwickelten neue, speziell auf aufstrebende Märkte mit niedrigerem Kostenund Technologieniveau zugeschnittene Produkte, um auf solchen ausländischen Märkten erfolgreich zu agieren. Deutsche Produzenten positionieren sich mit hochqualitativen Produkten immer noch am oberen Ende der Emerging Markets, aber Qualität ist eine relative und keine naturgegebene Kategorie. Folglich entwickeln deutsche Produzenten derzeit technische Kompetenzen vor Ort und verbessern ihr System zur Reduzierung der Auslandskosten, um ihre Wettbewerbssituation zu festigen: Der Einkauf wird regionalisiert, Kompetenzen im Bereich technische Konstruktion werden im Ausland ausgeweitet, und formale Verfahren zur Selbstoptimierung und Kostensenkung als Teil ganzheitlicher Produktionssysteme werden globalisiert.

Diese Änderungen haben mit strategischen Veränderungen und Produktionsverlagerungen entscheidende Auswirkungen für die Unternehmensstrategie, die Organisation der Produktion, Industriestrukturen und Arbeitsmärkte innerhalb Deutschlands. Deutsche Produktionsstandorte stellen weiterhin Exportgüter in hoher Qualität her. Tatsächlich veranlasst die gleiche Produce-where-you-sell-Logik (,,produzieren wo man verkauft"), die die Unternehmen veranlasst, ihre Produktions- und Entwicklungstätigkeiten im Ausland auszuweiten, sie zugleich dazu, Produktion und Entwicklung im Inland zu halten. Die Produktionslandschaft und die Arbeitsmarktstruktur im Inland sind aber einem starken Wandel unterworfen. Einerseits nehmen die Arbeitskräfte in der direkten Produktion im Inland ab, da die Nachfrage in Exportmärkten deutlich langsamer wächst als 
die Produktionsinvestionen im Ausland. Andererseits übernehmen Kompetenzen im Bereich Technik und Konstruktion im Inland eine Unterstützungsfunktion für technische Experimentierprozesse multinationaler Unternehmen. Solche Aktivitäten wachsen analog $z u$ Auslandskompetenzen und der Ausweitung der Produktionskomplexität und vergrößern somit die Nachfrage nach Ingenieuren und Technikern. In Kombination führen diese beiden Entwicklungen zu einer grundlegenden Neuzusammensetzung der Belegschaften in der deutschen Industrie, selbst wenn das absolute Beschäftigungsniveau in der Industrie konstant bleibt.

Darüber hinaus werden die Kernbereiche der Industrie und des Arbeitsmarktes segmentiert. Dieses Phänomen hat viele Facetten. Erstens nimmt Zeitarbeit innerhalb der wichtigsten Unternehmen zu, da die Arbeitgeber versuchen, Kosten zu senken und die Flexibilität in Zeiten instabiler Konjunktur zu erhöhen. Zweitens ist die Segmentierung auch ein Ergebnis der anhaltenden vertikalen Desintegration in der Produktion. Ein extremes Beispiel sind die nicht in die Unternehmensstruktur eingegliederten Supplier-Parks in der Automobilindustrie, die sich aus unabhängigen Bauteilund Teilsystemherstellern zusammensetzen und große Montagekomplexe bedienen. Soweit diese überhaupt organisiert sind, sind Mitarbeiter solcher Supplier-Parks in zahlreichen verschiedenen (oder konkurrierenden) Gewerkschaften organisiert. Daraus entwickelt sich eine für Deutschland sehr untypische, stark segmentierte Tariflandschaft.

Drittens wurde die Segmentierung schließlich durch das Wiederauftreten von Zulieferern, die als verlängerte Werkbank fungieren, weiter verschärft. Die Steuerung globaler Tätigkeiten und die Ausweitung der Rollen, die sich daraus ergeben, belasten innerbetriebliche Tätigkeiten und Kapazitäten. Unternehmen sind nicht in der Lage, alles, was sie benötigen, mit den verfügbaren Ressourcen zu erreichen. Da sie nicht bereit sind, intern zu expandieren, verlagern die Unternehmen Bauteil- und Montagetätigkeiten in Unternehmen mit niedrigeren Kosten, um ihre laufenden Produktionsströme zu entlasten. Diese Subunternehmer fertigen lediglich Produkte nach den Blaupausen ihrer Kunden. Im Vergleich liegt ihr Vorteil in der Produktion von kleinen und mittleren Volumen mit extrem schnellem Durchlauf zwischen Auftrag und Lieferung. Im Gegensatz zu klassischen Lieferanten aus der verlängerten Werkbank fertigen diese neuen Produzenten, die zusätzliche Kapazitäten bereitstellen, oft mit exakt den gleichen Fertigungsmaschinen wie ihre Kunden, setzen weitgehend auf hochqualifizierte (jedoch nicht gewerkschaftlich organisierte und oft ausländische) Facharbeiter und beherrschen die komplexen Praktiken der Selbstoptimierung für Qualität und Kostensenkung in Zusammenhang mit den Produktionsverfahren der Unternehmen ihrer Kunden immer besser.
In dem Artikel werden all diese Aspekte des deutschen Produktionsmodells und seines Wandels dargelegt. Der erste Abschnitt diskutiert die strategische Verlagerung weg von Exporten, hin zur Fertigung im Ausland sowie die neuen globalen Produktstrategien und unternehmensinternen und unternehmensübergreifenden Steuerungsverfahren, die damit verbunden sind. Ein zweiter Abschnitt diskutiert dann die Folgen, die diese Verlagerung für die Tätigkeiten und Beziehungen im Inland hat. Schließlich werden Überlegungen zu den Implikationen angestellt, die diese Entwicklungen für das industrielle Beziehungsgeflecht und die Industriepolitik in Deutschland haben. Insgesamt besteht die Kernbotschaft dieses Beitrags darin, dass die aktuellen Prozesse der Produktionbsglobalisierung rekursiv sind, d. h. Schritte, die außerhalb Deutschlands unternommen werden, wirken sich auf allen Ebenen auf die Organisationsstrukturen und Verfahrensweisen innerhalb Deutschlands aus und verändern diese.

\section{References}

Alphametrics, and Ismeri Europa: Comprehensive sectoral analysis of emerging competences and economic activities in the European Union. DG employment, social affairs and equal opportunities April 2009: 1-114 (2012)

Artus, I.: Precarious delegates: irregular forms of employee interest representation in Germany. Industrial Relations Journal 44(4), 409-424 (2013)

Baccaro, L., Banassi C.: Softening Industrial Relations Institutions, Hardening Growth Model: the Transformation of the German Political Economy. Unpublished MS, Université de Genève pp 1-69 (2014)

Berger, S.: Making in America: from innovation to market. The MIT Press, Cambridge (2013)

Bergheim, S.: Global Growth Centres 2020. A guide for long-term analysis and forecasting, Deutsche Bank Research, presentation Washington, D.C., June 23, 2005 American Institute for Contemporary German Studies (2005)

Bosch, G., Haipeter, T., Latniak, E., Lehndorff, S.: Demontage oder Revitalisierung? Das Deutsche Beschäftigungsmodell Im Umbruch. Kölner Zeitschrift für Soziologie 64(839-853), 1-22 (2007)

Brandt, L., Thun, E.: The fight for the middle: upgrading, competition, and industrial development in China. World Development 38(11), 1555-1574 (2010)

Caves, R.E.: Multinational Enterprise and Economic Analysis, 3rd Edn. Cambridge University Press, New York (2007)

Clarke, C.: Automotive production systems and standardisation. from ford to the case of mercedes benz. Physica Verlag, Heidelberg (2005)

Dorn, D, Hanson, G.H., Autor, D.H.: The China syndrome: local labor market effects of import competition in the United States. MITNBER August 2011 (2011)

Dyck, S., Hansakul, S., Saxena, R.: Emerging Asia's Middle Class. A force to be reckoned with. Deutsche Bank Research, Current Issues. August 21, (2009)

Ebenstein, A., McMillan, M., Zhao, Y., Zhang, C.: Understanding the Role of China in the 'Decline' of US Manufacturing. Manuscript, Hebrew University of Jerusalem, November 2011 (2011)

Economist Intelligence Unit: Global Manufacturing Outlook: Growth while Managing Volatility, Global research commissioned by KPMG International from the Economist Intelligence Unit, 2011(2011) 
Eichhorst, W.: The unexpected appearance of a new German model. IZA Discussion Paper No. 6625, 1-26 (2012)

European Commission: Reaping the benefits of globalization. European Commission Staff Working Document SWD (2012) 299 final (2012)

Friedli, T., Schuh, G.: Wettbewerbsfähigkeit der Produktion an Hochlohnstandorten, 2nd edn. Springer Vieweg, Berlin (2013)

Fuchs, E., Kirchain, R.: Design for location? The impact of manufacturing offshore on technology competitiveness in the Optoelectronics industry. Manag Sci 56(12), 2323-2349 (2010)

Gerst, D.: Ganzheitliche Produktionssysteme Im Bereich Produktionsnaher Dienstleistungen. IG Metall PowerPoint, 1-23 (2010)

Gerst, Detlev: Intensivierung Von Arbeitszeit Durch GPS. IG Metall PowerPoint, 1-23 (2011)

Graham, I.: Automotive industry: trends and reflections. ILO, The Global Economic Crisis Sectoral Coverage WP 278, 1-217 (2010)

Haipeter, T.: "Perspektiven der Sozialpartnerschaft" in Stefan Schmalz and Klaus Dörre, eds, Comeback der Gewerkschaften? Campus, Frankfurt a. M., pp 115-130 (2013)

Hans Boeckler Stiftung. Ganzheitliche Produktionssysteme. http:// www.boeckler.de/42068.htm (2014)

Harrison, A., McMillan, M.: Offshoring jobs? Multinationals and US manufacturing employment. Rev Econ Stat 93(3), 857-875 (2011)

Hassel, A.: The Paradox of Liberalization-Understanding Dualism and the Recovery of the German Political Economy. LSE Working Paper Series 1-42 (2011)

Heil, B., Kuhlmann, M., Menrad, M.: Perspektiven Der Gestaltung Von Produktionssystemen Konzeptionelle Überlegungen Und Fallstudienbefunde. Goettingen: SOFI Working Paper (2013)

Herrigel, G., Wittke, V., Voskamp, U.: The process of Chinese manufacturing upgrading: transitioning from unilateral to recursive mutual learning relations. Glob Strat J 3(1), 109-25 (2013)

Herrigel, G., Wittke, V., Voskamp, U.: Globale Qualitätsproduktion und Globales Deutschland: MNCs, Rekursivität und Lokale Standort Wandlung, Hans Boeckler Stiftung Endbericht. Book Manuscript (2014)

Herrigel, G.: Industrial constructions. the sources of german industrial power. Cambridge University Press, New York (1995)

Herrigel, G.: Manufacturing possibilities. Creative action and industrial recompostiion in the USA, Germany and Japan. Oxford University Press, Oxford (2010)

Holst, H.: 'Commodifying institutions': vertical disintegration and institutional change in German labour relations. Work, Employment and Society 28(1), 3-20 (2014)

Jürgens, U., Krzywdzinski, M.: Competency development on the shop floor and industrial upgrading -Case study findings at Chinese auto makers. Paper delivered at the Second Industrial Co-development Conference, Copenhagen Business School, September 2012 (2012)

Kristensen, P.H., Lilja, K.: Nordic capitalisms and globalization. New forms of economic organization and welfare institutions. Oxford University press, Oxford (2010)

Mandel, M., Houseman, S.: Not all productivity gains are the same. Here's why. research.upjohn.org. (2011)

McKinsey Operations Practice: Manufacturing the Future: the Next Era of Global Growth and Innovation. McKinsey Global Institute, November 2012 (2012)

Moavenzadeh, J.: Offshoring automotive engineering: globalization and footprint strategy in the motor vehicle industry, report to the National Academy of Engineering, MIT International Motor Vehicle Program, December 1, 2006 (2006)

OECD: Recent Developments in the Automobile Industry. OECD Economics Department Policy Notes, No. 7. 2011: 1-13 (2011)

Reinhardt, W.: German electrical and electronic industry Industry structure allows hopes of early return to growth, Deutsche Bank Research, August 18, 2009 (2009)
Rollwagen, I., Renkin, T.: The global race for excellence and skilled labour: a status report. Deutsche Bank Research, 2012 (2012)

Sabel, C.F.: A real-time revolution in routines. In: Heckscher C., Adler P.S. (eds.) The corporation as a collaborative community. Oxford University Press, New York pp. 1-51 (2005)

Sabel, C.F.: Individualised service provision and the new welfare state: are there lessons from Northern Europe for developing countries? In: de Mello L., Dutz M.A. (eds.) Promoting inclusive growth, challenges and policies. OECD Publishing, 2012 (2012)

Sabel, C.F., Simon, W.: Minimalism and Experimentalism in the Administrative State. Georgetown Law Journal 100(1), November 2011 (2011)

Sabel, C.F., Zeitlin, J.: Experimentalist Governance. In: Levi-Faur D. (ed) The Oxford Handbook of Governance. Oxford University Press, Oxford (2012)

Schmalz, S., Dörre, K. (eds.): Comeback der Gewerkschaften? Machresourcen, innovative Praktiken, international Perspektiven. Campus Verlag, Frankfurt a. M., (2013)

Slaughter, M.J.: American Companies and Global Supply Networks Driving U.S. Economic Growth and Jobs by Connecting with the World. Business Roundtable; United States Council for International business; United States Council Federation 1-64 (2012)

Spear, S.J.: Chasing the Rabbit. McGraw Hill, New York, (2009)

Speed, T.: Beyond the Japanese Production Model, PhD Dissertation, Australian National University, Department of International Relations (2009)

Spence, M., Sandile, H.: The Evolving Structure of the American Economy and the Employment Challenge. Council on Foreign Relations Working Paper, March 2011 (2011)

Spermann, A.: The new role of temporary agency work in Germany. IZA Discussion Paper No. 6180: 1-54 (2011)

Thelen, K., Palier, B.: Institutionalizing Dualism: complementarities and change in France and Germany. Polit Soc 38, 119-148 (2010)

Trinh, T.: Asia 2010 + trends determining emerging Asia's future. Deutsche Bank Research, September 18, 2006 (2006)

VDA: Jahresbericht. Frankfurt a. M. (2008)

Walter, N.: Germany 2020, New challenges for a land on expeditionand food for thought for the EU, Brussels, October 3, 2007 (2007)

Zysman, J., Breznitz, D.: Double bind: governing the economy in the ICT era. Gov Int J Policy, Adm Ins 25(1), 129-150 (2012)

Gary Herrigel is Professor of Political Science and the College, University of Chicago. He has published widely on the politics of industrial change in Europe, the United States and Japan, combining nuanced historical analysis and deep familiarity with social theory with detailed interview based qualitative research on contemporary developments in manufacturing. His academic publications have been widely cited and he has consistently engaged on a practical level in public debates on industrial change and business strategy in the United States and Europe. His main area of concentration in Europe has been Germany, where he has maintained a twenty year long collaboration with the SOFI Institute in Göttingen.

Fields of interest: political economy, business strategy, economic sociology, economic geography.

Books: Manufacturing Possibilities. Creative Action and Industrial Recomposition in the United States, Germany and Japan, (Oxford University Press, 2010); Americanization and its Limits, Reworking American Management and Technology in Europe and Japan since World War II, (Oxford University Press, 2000) (with Jonathan Zeitlin, editor); Industrial Constructions: The Sources of German Industrial Power, Cambridge University Press, 1996. 